\title{
Electronic markets in emerging markets
}

\author{
Xiongfei Cao $^{1} \cdot$ Sohail Chaudhry ${ }^{2} \cdot \mathrm{Li} \mathrm{Da} \mathrm{Xu}^{3}$
}

Received: 15 March 2019 / Accepted: 17 March 2019 / Published online: 29 March 2019

(C) Institute of Applied Informatics at University of Leipzig 2019

Electronic markets and networked business is one of most challenging areas for industry and research communities. Electronic markets have evolved from the classic article on the Electronic market hypothesis published in Communications of the ACM in 1987 to the highly integrated and collaborative e-business such as Alibaba (Malone et al. 1987; Wang et al. 2008). This evolution has reshaped the ways of doing business and supply chain networks (Peruzzini and Stjepandić 2018). In last two decades, we have seen how novel and dynamic electronic markets applications have been bringing about a variety of new developments, new organizational forms and shapes in respective industries. In the last decade, one of the most fundamental trends is the emergence of markets such as China, India, Brazil, and Russia as drivers of global economic growth (Li 2013). The emerging markets account for more and more world exports. Emerging markets including the emerging market country classifications have been defined in the literature (Atilgan et al. 2016). We believe that there are significant opportunities for improving our

This article is part of the Topical Collection on Electronic markets in emerging markets

\section{Responsible Editors: Rainer Alt and Hans-Dieter Zimmermann}

Xiongfei Cao

caoxf@hfut.edu.cn

Sohail Chaudhry

sohail.chaudhry@villanova.edu

Li Da Xu

1xu@odu.edu

1 Hefei University of Technology, Hefei 230009, China

2 Villanova University, Villanova, PA 19085, USA

3 Old Dominion University, Norfolk, VA 23529, USA understanding of electronic markets in emerging economies, in ways that also advance theories of electronic markets and their impact on both developed and developing (emerging) economies.

The purpose of this Special Issue is to provide an opportunity to bring together the research of scholars around the world to address issues related to electronic markets in emerging markets. This special issue of Electronic Markets presents four papers authored by scholars from the US, UK, Canada, and China. To prepare for this issue, all authors were asked to respond to at least two rounds of peer review. Each paper emphasizes the importance of Electronic Markets in Emerging Markets from a unique perspective.

Online to offline $(\mathrm{O} 2 \mathrm{O})$ is defined as e-commerce that combines searching and booking products or services online, and consumption in brick-and-mortar stores. Both China and other countries have witnessed the rise of $\mathrm{O} 2 \mathrm{O}$ e-commerce platforms in recent years. The paper by Wan and Chen (2019) studies this rapid development from the supply side of $\mathrm{O} 2 \mathrm{O}$ e-commerce platforms. The results of this empirical study partially support that vertical integration has a negative impact on the relationship between platform choice and suppliers' efficiency.

The authors of the paper entitled "Entrepreneurial Bricolage and Online Store Performance in Emerging Economies" (Yu et al. 2019a) developed a novel framework to explore the relationships between different types of entrepreneurial bricolage and online store performance, using data from the largest third-party ecommerce platform in China, Alibaba's Taobao.com. The researchers found that input bricolage had a positive effect on efficiency performance and market bricolage had a positive effect on sales performance, and these relationships were significantly stronger with higher levels of institutional bricolage. This study contributed to the development of entrepreneurial bricolage theory through a detailed exploration of the effects of different types of entrepreneurial bricolage, and could assist SMEs to make use of resources at hand in applying entrepreneurial bricolage. 
The paper entitled "Success Factors and Complex Dynamics of Crowdfunding: An Empirical Research on Taobao Platform in China" (Xie et al. 2019) conducted a multi-period, multi-party simulation study that evaluates crowdfund raisers' project positioning decisions and investors' project funding decision in a massive market. Taobao is a Chinese online shopping website owned by Alibaba. It is the world's largest e-commerce website. Their research results reveal that dynamics of a crowdfunding market are rather complex. These insights contribute to an in-depth theoretical understanding of crowdfunding, as well as providing guidance to crowdfund raisers, investors, and administrators.

Although it is well established in the literature that social networks affect firm performance, few studies have quantified the effects on online store performance, particularly in an emerging economy context. In the paper entitled "Social Networks and Online Store Performance in Emerging Economies: The Mediating Effect of Legitimacy" (Yu et al. 2019b), the insights obtained contribute to an in-depth understanding of the relationship between social networks and online store performance in emerging economies. This research also discussed theoretical contributions, managerial implications, and future research directions.

We hope that this special issue will serve our Electronic Markets readers as an avenue to gain a current perspective on Electronic Markets in Emerging Markets. We are also deeply grateful to the editorial board members and individual reviewers who worked with us so diligently. Without their time, effort, and support, this issue would never have come to be.

\section{References}

Atilgan, Y., Demirtas, K. O., \& Simsek, K. D. (2016). Derivative markets in emerging economies: a survey. International Review of Economics \& Finance, 42, 88-102.

$\mathrm{Li}, \mathrm{L}$. (2013). The path to made-in-China: How it was done and future prospects. International Journal of Production Economics, 146(1), 4-13.

Malone, T. W., Yates, J., \& Benjamin, R. I. (1987). Electronic markets and electronic hierarchies. Communications of the ACM, 30, 484- 497.

Peruzzini, M., \& Stjepandić, J. (2018). Editorial to the special issue "transdisciplinary analytics in supply chain management". Journal of Management Analytics, 5(2), 75-80.

Wan, X., \& Chen, J. (2019). The relationship between platform choice and supplier's efficiency- evidence from China's online to offline $(\mathrm{O} 2 \mathrm{O})$ e-commerce platforms. Electron Markets. https://doi.org/10. 1007/s12525-017-0280-3.

Wang, S., Zheng, S., Xu, L., Li, D., \& Meng, H. (2008). A literature review of electronic marketplace research: Themes, theories and an integrative framework. Information Systems Frontiers, 10(5), 555-571.

Xie, K., Liu, Z., Chen, L., et al. (2019). Success factors and complex dynamics of crowdfunding: An empirical research on Taobao platform in China. Electronic Markets. https:// doi.org/10.1007/s12525-018-0305-6.

Yu, X., Li, Y., Chen, D. Q., et al. (2019a). Entrepreneurial bricolage and online store performance in emerging economies. Electronic Markets. https://doi.org/10.1007/s12525-018-0302-9.

Yu, X., Tao, Y., Chen, Y., Zhang, W., \& Xu, P. (2019b). Social networks and online store performance in emerging economies: The mediating effect of legitimacy. Electronic Markets. https://doi.org/10.1007/ s12525-019-00333-2.

Publisher's note Springer Nature remains neutral with regard to jurisdictional claims in published maps and institutional affiliations. 